\title{
A Rare Cause of Fever in the Emergency Department: Anhidrotic Ectodermal Dysplasia
}

\author{
Acil Serviste Ateşin Nadir Bir Nedeni: Anhidrotik Ektodermal Displazi
}

\author{
Asım KALKAN, ${ }^{1}$ Selman YENIOCAK, ${ }^{2}$ Özlem BiLIR,, Gökhan ERSUNAN,' Baris GIAKOUP'1 \\ 'Department of Emergency Medicine, Recep Tayyip Erdogan Univercity Faculty of Medicine, Rize; \\ ${ }^{2}$ Department of Emergency Medicine, Haseki Education and Research Hospital, Istanbul
}

\begin{abstract}
SUMMARY
Ectodermal dysplasia is a rare disease that present with: hypotrichosis, hypodontia, and typically absence of eccrine sweating. It consists of two basic forms; anhidrotic and hidrotic. In anhidrotic ectodermal dysplasia, the body's thermoregulatory mechanism is impaired due to lack of sweat glands. These patients may therefore present to the emergency department with hyperthermia. This report describes a patient with anhidrotic ectodermal dysplasia brought to the emergency department in an unconscious state and with a fever of $41^{\circ} \mathrm{C}$. This rare disease should be kept in mind in patients presented to ED with an unconscious state due to hyperthermia. Typical clinical appearance is a useful clue for the diagnosis. Proper antipyretic therapy is sufficient for the treatment.
\end{abstract}

Key words: Anhidrotic ectodermal dysplasia; hyperthermia.

\section{ÖZET}

Ektodermal displazi, hipotrikozis (tüylerin yokluğu), anadonti (dişlerin yokluğu) ve tipik olarak ekrin ter bezlerinin yokluğu ile kendini gösteren nadir bir hastalıktır. İi temel form içerir, anhidrotik ve hidrotik. Anhidrotik ektodermel displazide (AED) ter bezleri olmadığından vücudun termoregulatuvar mekanizması bozuktur. Bu hastalar acil servise hipertermi ile başvurabilir. Bu yazıda, bilinç kapalılığı ve $41^{\circ} \mathrm{C}$ ateş nedeni ile acil servise getirilen anhidrotik ektodermal displazili bir hasta sunuldu. Bu nadir görülen hastalık hipertermi nedeni ile bilinci kapalı anhidrotik ektodermal displazili hastalarda akılda bulundurulmalıdır. Tipik klinik görüntüsü tanı koymakta faydalıdır. Uygun antipiretik terapi tedavisi için yeterlidir.

Anahtar sözcükler: Anhidrotik ektodermal displazi; hipertermi.

\section{Introduction}

Ectodermal dysplasia (ED) is a genetic disorder characterized by defective development of teeth, hair, nails, and eccrine sweat glands. The most prevalent form of ED is inherited as an X-linked condition; however, autosomal dominant and autosomal recessive forms of the disorder have been described. ED consists of two basic forms; anhidrotic and hidrotic. In anhidrotic ectodermal dysplasia (AED), the body's thermoregulatory mechanism is impaired due to lack of sweat glands. Clinical features of AED include sparse and fine hair, missing or conical-shaped teeth, decreased sweat and mucous glands, hypoplastic skin, and heat intolerance with exercise or increased ambient temperature. ${ }^{[1]}$ The greatest risk arises from their inability to sweat that result in episodes of severe hyperthermia. Mortality of ED is highest during the first year of life, but remains elevated throughout early childhood. Later in life, ambient temperatures of more than $25^{\circ} \mathrm{C}$, exposure to the sun, and physical exercise may cause serious hyperthermia, often constraining AED patients in their professional careers and daily activities, especially in sports and traveling. Body core temperatures increase during exercise

Submitted (Geliş tarihi): 17.09.2012 Accepted (Kabul tarihi): 08.11.2012 Published online (Online baskı): 14.02.2013

Correspondence (iletişim): Dr. Asım Kalkan. Fener Mahallesi, Zihni Derin Yerleşkesi, Merkez Kampüs, 53100 Rize, Turkey.

e-mail (e-posta): drasimkalkan@hotmail.com

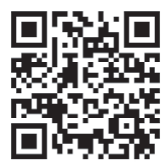

Türkiye Acil Tıp Dergisi - Tr J Emerg Med 2013;13(2):89-91

doi: $10.5505 / 1304.7361 .2013 .54366$ 
which may accelerate neuromuscular fatigue, reduce endurance, and performance or may even lead to dangerous conditions such as exertional heat stroke. ${ }^{[2]}$ Herein, we described a patient with AED who admitted to our emergency department in an unconscious state with hyperthermia. We discussed the clinical characteristics and management of this rare disease.

\section{Case Report}

A 20-year-old male patient was found in an unconscious state lying on the street and was brought to our emergency department. Upon admission, his pulse was $122 / \mathrm{min}$, blood pressure was $90 / 60 \mathrm{mmHg}$, respiration rate $22 / \mathrm{min}$, oxygen saturation $\% 84$ and body temperature $41^{\circ} \mathrm{C}$. There were no signs of trauma, swelling or echymosis over his body. At systematic examination, pulmonary auscultation was normal and the heart was rhythmic and tachycardic. At neurological examination the patient retracted the extremities following painful stimulus (Glasgow Coma Scale: 10). There was no nuchal rigidity and reflexes were normal. He had very spare and fine hair, beard and moustache, with eyelashes so few as to be non-existent (Figure 1a). Teeth were entirely prosthetic. The nasal root was collapsed, there was a pronounced supraorbital ridge and the ears were bowl-shaped and protruding (Figure 1b). The upper lip was protuberant. The skin was dry, hairless and smooth. Bedside blood glucose level was 130 $\mathrm{mg} / \mathrm{dl}$. Biochemical tests (blood urine nitrogen, creatinine, sodium, potassium, alanine aminotransferase, aspartate aminotransferase and thyroid function tests), electrolytes and hemogram were all normal. In order to exclude a possible intracranial pathology for unconsciousness we performed Cranial CT. Cranial CT revealed no remarkable pathology.

There were no pathological findings other than high fever to disclose his unconscious state. Intravenous fluid replacement $(1000 \mathrm{mlt} \mathrm{NaCl} / \mathrm{h})$ was performed. External cold pack application was applied and intravenous Metamizole sodium ( $1 \mathrm{gr}$ ) was given to reduce the fever. The fever gradually began declining and consciousness began to return. The patient regained full consciousness after approximately 4 hours. His past medical history revealed that he had anhidrotic ectodermal dysplasia and had walked around in the sun for some $3 \mathrm{~h}$ that day. The patient was aware of his disease and knew that he should not do exercise in hot weather but he never had a situation like this before in similar weather conditions. The patient was discharged in a healthy condition at the sixth hour.

\section{Discussion}

Ectodermal dysplasia is a group of diseases presented with a characteristic triad of symptoms; hypotrichosis, anodontia and anhidrosis. It is seen in $1 / 100000$ live births across all races. It mainly affects males ( $90 \%$ of the cases) ${ }^{[3]}$ One hundred fifty-four types in 11 subgroups have been described. ${ }^{[4]}$ Ectodermal dysplasia is frequently seen in two forms, anhidrotic and hidrotic. Anhidrotic ectodermal dysplasia is transmitted as an autosomal recessive trait, and is less common than the hidrotic form. ${ }^{[5]}$ Characteristics of the syndrome were first described by Darwin. ${ }^{[5,6]}$ The genetic and transmitted aspects and clinical characteristics were described by Christ, Siemens and Touraine..$^{[7]}$ The main characteristics of this rare disease are sparse, fine and short hair eyebrows and eyelashes, soft, smooth and dry skin and sparse yellow hairs covering the entire body. In facial appearance the nasal root is depressed, there is a pronounced supraorbital ridge and dry, protuberant lips and prominent ear bowls. In the oral cavity, a high palate and flawed dental structure can be (a)

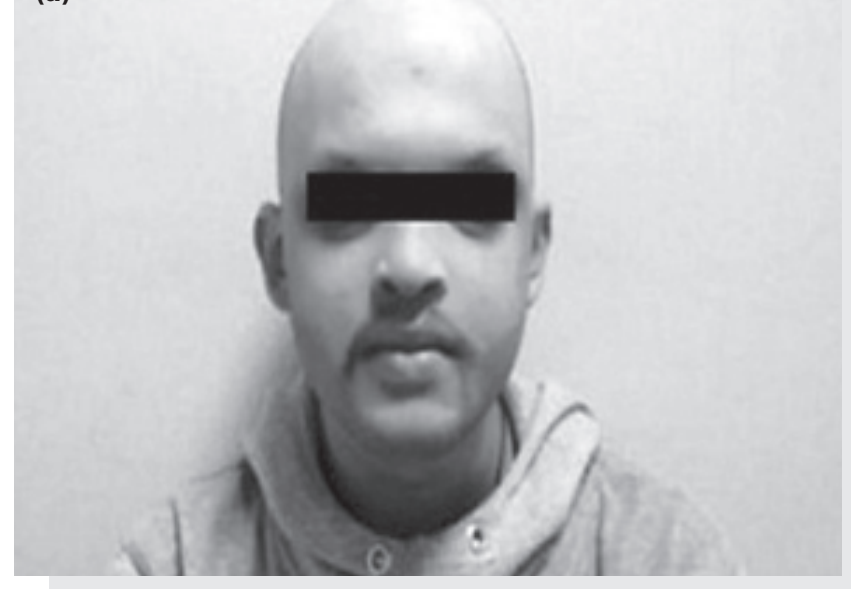

(b)

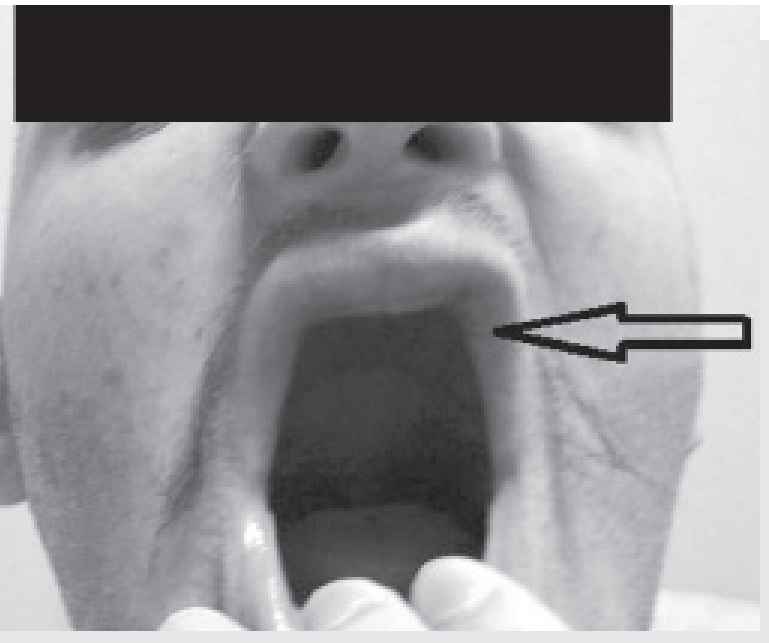

Figure 1. (a) Typical facial and skin findings. In facial appearance the nasal root is depressed, there is a pronounced supraorbital ridge and dry, protuberant lips and prominent ear bowls. (b) Anodontia. In the oral cavity, a high palate and flawed dental structure can be seen. 
seen. Teeth may be totally or partially absent. Diagnosis is made on the basis of typical clinical findings. ${ }^{[8]}$ Our patient's appearance matched the majority of descriptions in the literature. Eczema, frequent infections and unexplained fever are other diagnostic clues. ${ }^{[9]}$ Nijs et al. ${ }^{[10]}$ reported repeating high fever in a nine-month-old male patient brought to the emergency department for that reason and described the approach they adopted. Patients presenting to the emergency department with different clinical conditions can easily be treated when their diseases are known. But if the disease is overlooked, this can give rise to poor outcomes because of the severe loss of time involved.

The mechanism that regulates body temperature is the thermoregulatory center in the hypothalamus. Ambient temperature changes can be controlled by this center without a change in body temperature. As the surrounding temperature rises, body temperature is reduced through vasodilatation in the skin capillaries and increased sweating. These patients, with no sweat glands, can develop hyperthermia in excessively hot weather. And hyperthermia can result in loss of consciousness. Our patient had a fever of 41 degrees. Awareness of the typical facial and skin findings of the disease would have facilitated management of this patient brought to the emergency department.

There is no specific treatment for ectodermal dysplasia. Patients are advised to avoid extreme heat and excessive activity. Patients whose temperatures rise must be kept in environments where the ambient temperature is reduced. Air-conditioning, wet T-shirts and cold showers are simple measures for preventing fever developing. ${ }^{[1]}$ We performed cold treatment with wet cloths in our case. Fever declined fell progressively and consciousness returned.

\section{Conclusion}

Patients with ED may present to the emergency department with hyperthermia-associated loss of consciousness. Typical facial appearance and absence of teeth may help to identify this rare disease. Timely recognition of the condition may prevent unnecessary diagnostic work-up and provide faster treatment. ED physicians should keep this rare disease in mind with high fever and unconscious state.

\section{Conflict of Interest}

The authors declare that there is no potential conflicts of interest.

\section{References}

1. Ermertcan AT, Yaşar A, Kayhan TÇ, Gülen H, Ertan P. Hypohidrotic ectodermal dysplasia associated with glucose-6-phosphate dehydrogenase deficiency. Ann Dermatol 2011;23:810. [CrossRef]

2. Hammersen JE, Neukam V, Nüsken KD, Schneider H. Systematic evaluation of exertional hyperthermia in children and adolescents with hypohidrotic ectodermal dysplasia: an observational study. Pediatr Res 2011;70:297-301. [CrossRef]

3. Balcı G, Başkan SZ, Akdeniz S. Ectodermal Dysplasia: Report of Four Cases and Review of Literature. International Dental and Medical Disorders 2008;1:56-9.

4. Nordgarden H, Johannessen S, Storhaug K, Jensen JL. Salivary gland involvement in hypohidrotic ectodermal dysplasia. Oral Dis 1998;4:152-54. [CrossRef]

5. Bani M, Tezkirecioglu AM, Akal N, Tuzuner T. Ectodermal dysplasia with anodontia: a report of two cases. Eur J Dent 2010;4:215-222.

6. Virginia PS, Zonana J. Ectodermal dysplasias. In: Bolognia JL, Jorizzo JL, Rapini RP, editors. Dermatology. 2th ed. Edinburg: Mosby; 2003. p. 874-81.

7. Palit A, Inamadar AC. What syndrome is this? Christ-SiemensTouraine syndrome (anhidrotic/hypohidrotic ectodermal dysplasia). Pediatr Dermatol 2006;23:396-8.

8. Cambiaghi S, Restano L, Pääkkönen K, Caputo R, Kere J. Clinical findings in mosaic carriers of hypohidrotic ectodermal dysplasia. Arch Dermatol 2000;136:217-24. [CrossRef]

9. Özçetin M, Özer I. Ectodermal dysplasia: rare cause of relapsing fever. Cumhuriyet Med J 2009;31:189-90.

10. Nijs EL, Huisman TA. Recurrent fever and lack of tooth buds. A case of ectodermal dysplasia in a 9 months old boy. JBR-BTR 2001;8:256-7.

11. McDermott BP, Casa DJ, Ganio MS, Rebecca M Lopez, Susan W Yeargin, Lawrence E Armstrong, Carl M Maresh. Acute whole-body cooling for exercise-induced hyperthermia: a systematic review. J Athl Train 2009;44:84-93. [CrossRef] 